\title{
VÝSTAVBA LANOVÝCH DRÁH NA SLOVENSKU POMOCOU VRTUL'NÍKOV
}

\section{CONSTRUCTION OF ROPEWAYS IN SLOVAKIA USING HELICOPTERS}

\author{
Ing. Andrej Bisták, PhD. ${ }^{1 *}$; doc. Ing. Zdenka Hulínová, PhD. ${ }^{1}$ \\ ${ }^{1}$ Slovenská technická univerzita v Bratislave, Stavebná fakulta, Radlinského 11, 81005 Bratislava, Slovensko \\ *korespondenčni autor: andrej.bistak@stuba.sk
}

\section{PƯVODNí VĚDECKÝ PŘísPĚVEK}

ORIGINAL SCIENTIFIC ARTICLE

\begin{abstract}
ABSTRAKT SK
Lanové dráhy obyčajne sprístupňujú lokality, ktoré nie sú dosiahnutel’né žiadnym iným dopravným prostriedkom, preto je ich výstavba technologicky a logisticky mimoriadne náročná. Stavenisko lanovej dráhy sa väčšinou nachádza $\mathrm{v}$ exponovanom teréne, ktorý často pri výstavbe neumožňuje použitie bežných stavebných strojov. V takom prípade je vhodné využit' dopravné prostriedky, ktorých prevádzka nie je závislá od charakteru terénu - vrtul'níky. Vrtul'níky ako „lietajúce žeriavy“ sa v našom stavebníctve používajú už viac ako šest' desat'ročí. V druhej polovici 60. rokov 20. storočia použitie vrtul'níkov práve pri výstavbe lanoviek ešte akcentoval podnik Transporta Chrudim, vtedajší monopolný domáci výrobca lanových dráh. Po získaní pozitívnych skúseností, najmä v segmente lanovej dopravy, sa vrtul'níky začali uplatňovat' aj v d’alších „konvenčných“ oblastiach stavebníctva. Postupne sa potvrdzovali výhody využitia tejto technológie pri rôznych druhoch stavebných prác a použitie vrtul'níkov bolo začlenené do bežných technologických postupov. Pri výstavbe lanoviek sú jej neodmyslitel'nou súčast'ou dodnes.
\end{abstract}

Klíčová slova: Lanovka; vrtul'ník; stavebné procesy; simulačné modelovanie; logistika

\begin{abstract}
Ropeways usually provide access to sites that are not accessible by any other types of transport. Due to this fact, the construction of ropeways is technologically and logistically extremely demanding. The construction site is situated mostly in exposed terrain, which often does not allow the use of conventional construction machinery in their construction. In this case, it is advisable to use means of transport that are not dependent on the character of the terrain - helicopters. Helicopters as "flying cranes" have been used by our building industry for over six decades. In the second half of the 1960s, the use of helicopters in the construction of ropeways was accentuated by Transporta Chrudim, a monopolistic domestic ropeway manufacturer. After gaining positive experiences, especially from the transportation by rope segment, helicopters began to be used by the then "conventional" building industry. Gradually, the benefits of execution of different types of construction work were confirmed, and in the following years the use of helicopters was incorporated in the main technological procedures. The construction of ropeways is an essential part of it until today.
\end{abstract}

Key words: Ropeway; helicopter; construction processes; simulation modelling; logistics 


\section{1 ÚVOD}

Vrtul'ník, vzhl'adom $\mathrm{k}$ svojim vlastnostiam, predstavuje praktický a nenahraditel'ný dopravný prostriedok pre mnohé odvetvia. Možnost' kolmého štartu a pristátia bez závislosti na dlhých vzletových a pristávacích dráhach poskytuje vrtul'níkom neobyčajne široký operačný priestor, pretože na pristátie a štart nevyžadujú rozmernú ani špeciálne upravenú plochu. Netradičné manévrovacie schopnosti umožňujú vrtul'níkom vykonávat' lety aj v tesnej blízkosti terénu. Nižšia dopravná rýchlost' vrtul'níkov oproti iným leteckým prostriedkom je v prípade dopravy bremien výhodou [1]. Vrtul’ník je schopný letiet' všetkými smermi a na rozdiel od klasických lietadiel umožňuje aj zastavenie vo vzduchu - visenie. Práve kombinácia týchto charakteristických vlastností umožnila využitie vrtul'níkov aj v sektore stavebníctva [2].

Aj napriek ich zjavným výhodám boli vrtul'níky v niektorých prípadoch už prekonané novšími a efektívnejšími spôsobmi realizácie, napr. s využitím dronov (v literatúre označovaných často ako UAV - unmanned aerial vehicles, teda bezpilotných lietadiel). Drony majú široké uplatnenie a v oblasti stavebníctva slúžia napr. na kontrolu stavu elektrických vedení, nadzemných produktovodov, ciest, mostov, priehrad, tunelov, železničných tratí či zavlažovacích kanálov [3]. Vzhl'adom na ich zanedbatel'nú nosnost' však vrtul'níky zostávajú nad’alej t’ažko nahraditel'né v oblasti samotných stavebných prác a dopravy materiálu.

\section{PRVOPOČIATKY LETECKÝCH PRÁC NA NAŠOM ÚZEMÍ A ICH TECHNICKÝ ROZVOJ}

V našich podmienkach, teda v niekdajšom Československu, sa éra využitia vrtul'níkov v stavebnom priemysle začala $\mathrm{v}$ roku 1957, kedy bolo na strechu $42 \mathrm{~m}$ vysokej budovy pomocou vrtul'níka dopravených niekol'ko častí technického zariadenia [2]. Stavebnými prácami uskutočňovanými vrtul'níkom (označovanými aj ako letecké práce) sa v roku 1961 začali zaoberat' vtedajšie Československé aerolínie, ktoré zakúpili 2 vrtul’níky typu Mi-1 a Mi-4. S pomocou týchto strojov sa až do roku 1968 overovali možnosti uplatnenia vrtul'níkov pri rôznych druhoch stavebných prác.

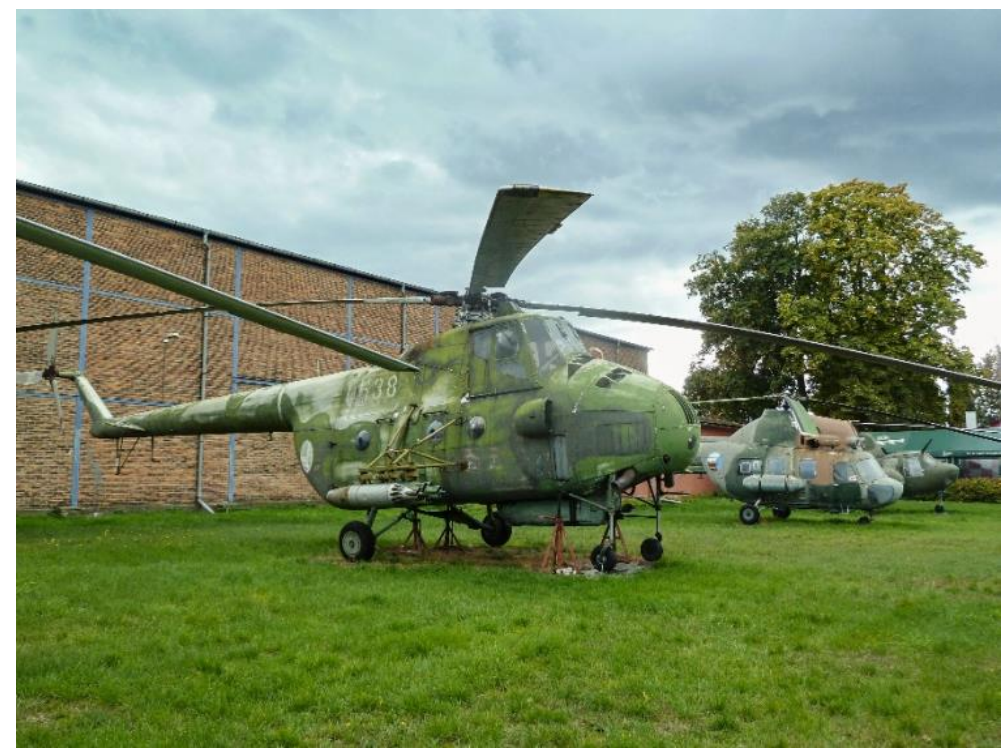

Obr. 1 Vrtul'níky typu Mi-4 (v popredí), Mi-2 (v strede) a Mi-1 (v pozadí) v Leteckom múzeu Praha-Kbely v septembri 2019 (autori) 
Vrtul'níky typov Mi-1 a Mi-4 (obr. 1) však nemali postačujúcu nosnost' (max. 200 - 1300 kg) a navyše boli vybavené iba jedným piestovým motorom. Po havárii vrtul'níka Mi-4, počas demontáže nákladnej lanovky v Sirku v roku 1966, boli tieto aktivity pozastavené a začalo sa hladanie vhodnejšieho modelu vrtul'níka, ktorý by spĺn̆al všetky požiadavky na vykonávanie leteckých prác [4].

V roku 1967 prišla na trh novinka - dodnes rozšírený stroj typu Mi-8. Ešte v tom istom roku získala dva vrtul'níky Mi-8 aj vtedajšia československá armáda. Vrtul'níky boli pridelené Vojenskému leteckému a výskumnému stredisku 031 Praha-Kbely, kde sa v marci 1968 uskutočnil skúšobný let s ocel'ovou podperou lanovej dráhy v podvese a jej pokusné usadenie na presne stanovený ciel'. Výsledky týchto skúšok preukázali, že vrtul’ník typu Mi-8 vyhovuje všetkým požiadavkám na vykonávanie leteckých prác a umožnili tiež potvrdit' nasledovné uvažované predpoklady [4]:

- $\quad$ hodnoty normálnej vertikálnej rýchlosti osadenia bremena získané z prevádzky vrtul'níkov Mi-4 zodpovedali predpokladanej hodnote $5-10 \mathrm{~cm} / \mathrm{s}$, čo bolo $\mathrm{v}$ súlade $\mathrm{s}$ rýchlost’ami zdvihu väčšiny vtedajších klasických žeriavov,

- dlhé bremeno (rúrová podpera) pri rôznych dížkach závesu $(5-20 \mathrm{~m})$ a pri rôznych rýchlostiach letu $(0-90 \mathrm{~km} / \mathrm{h})$ nespôsobovalo narušenie priebehu letu,

- $\quad$ pri skúšaní dosiahnutel'nej horizontálnej presnosti v etape konečného osadenia podpery na základovú pätku sa zistilo výrazné vertikálne kývanie bremena, ktoré zhoršovalo podmienky presného osadenia.

Po vykonaní skúšobných letov bol spracovaný technologický postup a vyrobené montážne prípravky pre zabezpečenie prvej akcie - dopravy a montáže 35 rúrových podpier dvojúsekovej sedačkovej lanovky Špičák - Pancír v českej Železnej Rude (obr. 2). Samotná montáž podpier prebehla v dňoch 28. mája - 1. júna 1968. Napriek nepriazni počasia (dážd', nízka oblačnost' a silný vietor) boli montážne procesy realizované za 5 hod. 38 min. čistého letového času. Celá stavba vrátane prípravy a ukončenia trvala iba 10 pracovných dní. Realizácia tejto montáže klasickou technológiou pritom počítala so 73 pracovnými dňami a cenou vyššou o 297 253,70 Kčs [4].

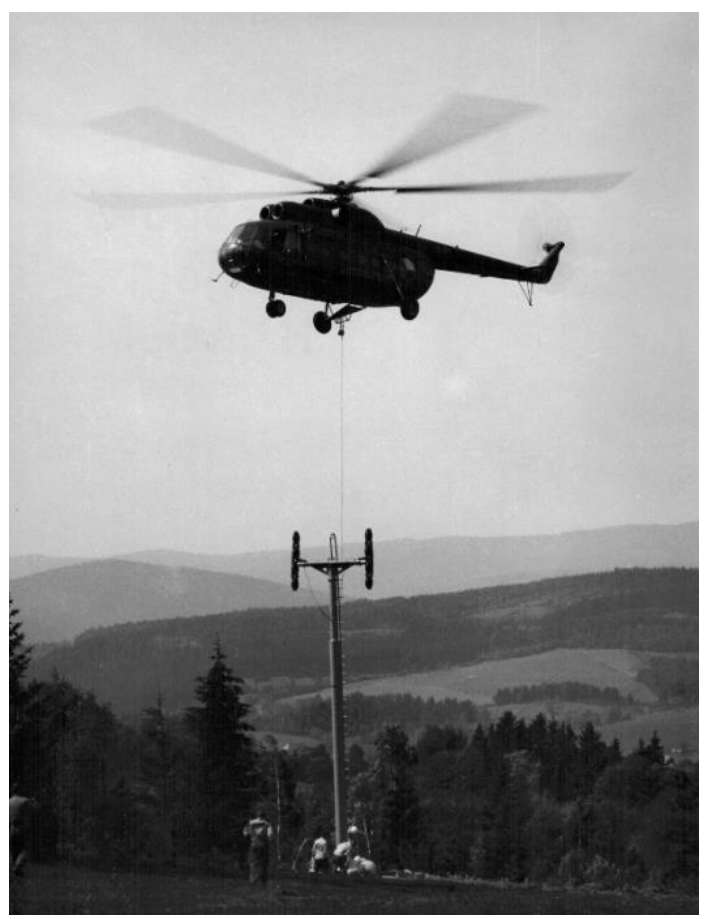

Obr. 2 Montáž rúrových podpier sedačkovej lanovky Špičák - Pancí̌ v Železnej Rude (Miroslav Holub) 
Pozitívne skúsenosti z tejto stavby podporili d’alší rozvoj vrtul'níkového programu. Hlavným iniciátorom využitia vrtul'níkov $\mathrm{v}$ celom stavebnom priemysle pritom bola niekdajšia Transporta Chrudim, $v$ tom čase domáci monopolný výrobca týchto lanových dráh. Jej montážny závod Tramontáž mal eminentný záujem na zefektívnení realizácie stavieb v náročných podmienkach, $\mathrm{v}$ tej dobe ešte stále málo mechanizovaných [5]. Do konca roku 1970 sa vlastnosti vrtul'níkov overovali aj pri stavebných prácach mimo „lanovkového“ sektora. Išlo napr. o montáž vysokých ocel’ových stožiarov elektrického vedenia, montáž potrubných mostov, obnovu zastaraných výrobných hál s komplikovaným prístupom, montáž a demontáž ocel’ových komínov a zariadení na strechy hál, montáž a demontáž anténnych systémov, vežových žeriavov a pod. [4]. V samotnom segmente lanovej dopravy nasledovalo niekol'ko d’alších prototypových akcií, z ktorých najvýznamnejšie uvádzame v nasledujúcej časti tohto článku.

\subsection{Montáž podpier priehradovej konštrukcie}

Po úspešnej realizácii spomenutej montáže podpier sedačkovej lanovej dráhy sa technický rozvoj v závode Tramontáž zameral na overenie montáže podpier kabínkových lanoviek [4]. Tieto podpery boli, na rozdiel od podpier sedačkových lanoviek, priehradovej konštrukcie a typicky dosahovali podstatne väčšie výšky a dimenzie, a teda aj hmotnosti.
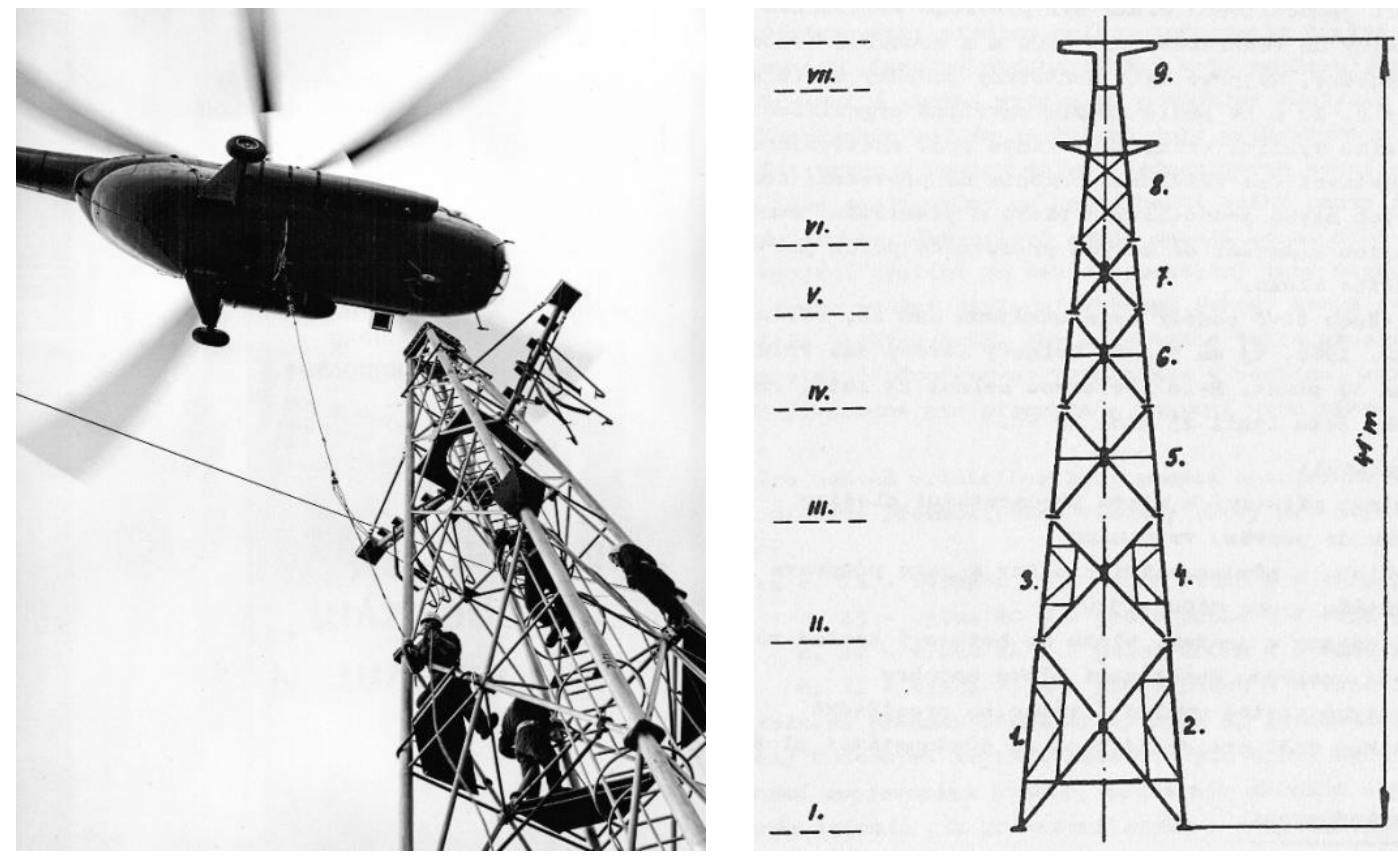

Obr. 3 Montáž priehradových podpier kabínkovej lanovky Tatranská Lomnica - Skalnaté pleso (3a) a typická zostava podpery s vyznačenými blokmi (3b) [4]

Overenie tohto typu prác sa uskutočnilo na stavbe kabínkovej lanovky Tatranská Lomnica - Štart Skalnaté pleso. V rámci tejto stavby bolo potrebné vykonat' montáž 4 trat'ových podpier (Obr. 3a). Konštrukcia podpier bola riešená ako priehradová s prírubovými stykmi v rovine rozdelenia jednotlivých sekcií - blokov. Jednotlivé sekcie boli na každej bočnej stene spojené iba jedným prírubovým stykom a nemali dolné ani horné priečne prepojenie, ktoré by zo sekcie vytvorilo samostatný tuhý blok. Výnimku tvorila iba dolná kotviaca sekcia vybavená priečnym zavetrením (Obr. 3b).

Aby bolo možné takto konštruované sekcie samostatne dopravovat' vrtul'níkom, museli byt' počas prepravy a montáže doplnené pomocnými tiahlami. Vo fáze montážnej prípravy sa teda použili 4 druhy 
montážnych prípravkov: prípravky na zabezpečenie tuhosti zostavy blokov, prípravky pre osadenie atypických dolných rozdelených sekcií jednej z podpier, prípravky zabezpečujúce pomocné navádzanie všetkých blokov a pomocné plošiny, umožňujúce pracovníkom zhotovenie stykov vo výške a manipuláciu pri usadzovaní blokov nesených vrtul’níkom.

Na predmontážnej ploche, umiestnenej vedl'a futbalového ihriska v Tatranskej Lomnici, sa pomocou autožeriava predmontovali všetky bloky pre montované podpery. Podpery mali výšku $20-41 \mathrm{~m}$ a skladali sa zo 4 - 8 blokov s hmotnost'ou 750 - 2300 kg. Samotná plocha ihriska sa využívala ako miesto pre vzlet a pristátie vrtulníka a doplńanie paliva. Doprava jednotlivých blokov sa vykonávala z predmontážnej plošiny na miesta montáže $\mathrm{v}$ teréne (základové pätky podpier) vzdialené vzdušnou čiarou 4,6 - $5 \mathrm{~km}$. Montáž podpier sa začala 14. októbra a ukončila 19. októbra 1968, teda trvala 5 pracovných dní. Celkový letový čas vrtul'níka bol 9 hod. 16 min. a spolu sa vykonalo 25 letov s priemerným trvaním jedného letu 25 min. 12 s. Po úspešne vykonanej realizácii sa konštatovalo, že cena za montáž vrtul'níkom bola o 660798 Kčs nižšia ako pri použití klasickej technológie a čas montáže sa skrátil o 121 pracovných dní [4].

\subsection{Betonáž základových pätiek a montáž rúrových podpier}

Sedačková lanovka Štrbské Pleso - Solisko, opät’ s technológiou z Transporty Chrudim, bola do prevádzky uvedená pri príležitosti majstrovstiev sveta v lyžovaní, uskutočnených na Štrbskom Plese vo februári 1970. Montážny závod mal začat' práce 1. júna 1969. V tom čase však neboli vyhotovené všetky výkopy pre základové pätky 38 trat’ových podpier a neboli realizované ani žiadne betonárske práce. Betonáž pätiek s využitím pomocnej lanovky a koša na betón s objemom $0,5 \mathrm{~m} 3$ sa začala 10 . júna 1969. Jazda koša k základu podpery č. 36, situovanej ned’aleko hornej stanice, a naspät’ trvala cca 5 hodín. Na stavbe sa pritom malo zabudovat' asi $650 \mathrm{~m} 3$ betónu, čo navrhnutou technológiou nebolo realizovatel'né ani do konca roku 1969.

Na žiadost' investora Tramontáž navrhla a realizovala betonáž základových pätiek pomocou vrtul'níka. Čerstvý betón bol dopravovaný od 11. augusta do 5. septembra 1969 na ten účel vyvinutým kontajnerom. Následne boli 3. októbra, teda za jeden deň, vrtul'níkom osadené i všetky podpery (Obr. 4). Použitie vrtul'níka na tejto stavbe tak skrátilo dobu montáže trat'ových podpier o 90 pracovných dní, čo prispelo k vyrovnaniu časových sklzov a umožnilo odovzdat' lanovku do užívania v stanovenom termíne [4].

Montážny závod Tramontáž uskutočňoval pomocou vrtul'níka montáž už všetkých nasledujúcich sedačkových lanoviek. Medzi prvé „sériové“ montáže, realizované do roku 1974, patrili montáže týchto lanových dráh:

- Železná studnička - Kamzík (Bratislava),

- $\quad$ Turecká - Krížna (Turecká),

- Banská Bystrica - Srnková (Banská Bystrica),

- Podstráne - Martinské hole (Martin), išlo o lanovku umiestnenú vo vel’mi náročnom teréne, kde sa v spoločnom lesnom prieseku nachádzalo súbežne s trat'ou budovanej lanovej dráhy aj $110 \mathrm{kV}$ vzdušné elektrické vedenie pre napájanie vysielača. Táto komplikovaná stavba sa úspešne dokončila v júni 1973 [4]. 


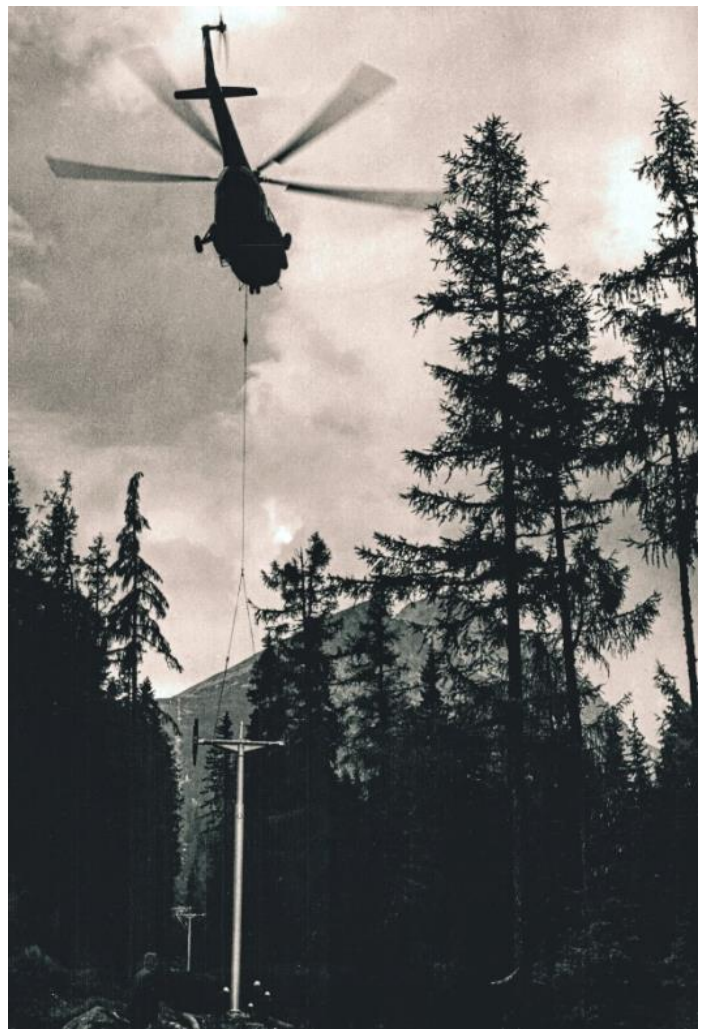

Obr. 4 Montáž podpier sedačkovej lanovky Štrbské Pleso - Solisko (Miroslav Holub)

\section{SÚČASNOSŤ LETECKÝCH PRÁC V SEKTORE LANOVEJ DOPRAVY}

Charakter a uplatnenie leteckých prác pri výstavbe lanoviek sa do dnešných dní prakticky nezmenili, v súčasnosti sa však vrtul'níky v Slovenskej republike používajú už pri výstavbe takmer každej novej lanovky. V posledných rokoch to boli napríklad lanové dráhy Oravská Lesná - Kohútik, Krupová Kosodrevina (Chopok juh), Ždiar - Vtáčie turne, Roháče - Spálená, Lúčky - Vyhliadka (Chopok sever) a Štart - Skalnaté pleso (Tatranská Lomnica). Jednou z najsledovanejších akcií bola výstavba nového lanovkového prepojenia severnej a južnej strany Chopku v rokoch 2011 -2012, ktoré je tvorené lanovou dráhou Priehyba - Chopok zo severu a lanovou dráhou Kosodrevina - Chopok z juhu.

Pre dnešné lanovky je vo všeobecnosti charakteristický väšší počet potrebných letov v porovnaní so staršími zariadeniami, opisovanými v predchádzajúcej kapitole, a to vzhl'adom na vyššie zat’aženia pôsobiace na konštrukčné prvky a s tým súvisiace zväčšenie potrebných dimenzií nosných ocel'ových konštrukcií. V dôsledku vyššej hmotnosti podpier, ktorá presahuje technické možnosti vrtul'níkov, sa podpery už v projekčnej etape rozdel'ujú na stanovený počet segmentov. Tieto segmenty sa na stavbe spájajú typicky pomocou prírub so skrutkovými spojmi, pričom presné osadenie susediacich dielov zabezpečujú montážne prípravky (Obr. 5). Na kompletné zhotovenie jednej podpery je teda potrebné uskutočnit' niekol'ko letov. Za tým účelom výrobca strojného zariadenia lanovky, ktorý je tradične v segmente lanovej dopravy obvykle aj výrobcom jej nosných konštrukcií, poskytuje dodávatel'ovi leteckých prác tabul'ky s uvedením presného počtu dielcov, ich rozmerov (dížok) a hmotností. Na základe hmotnostných tabuliek realizátor následne vypracuje technologický postup montáže, najmä rozdelenie segmentov do jednotlivých letov a celkové poradie letov. 


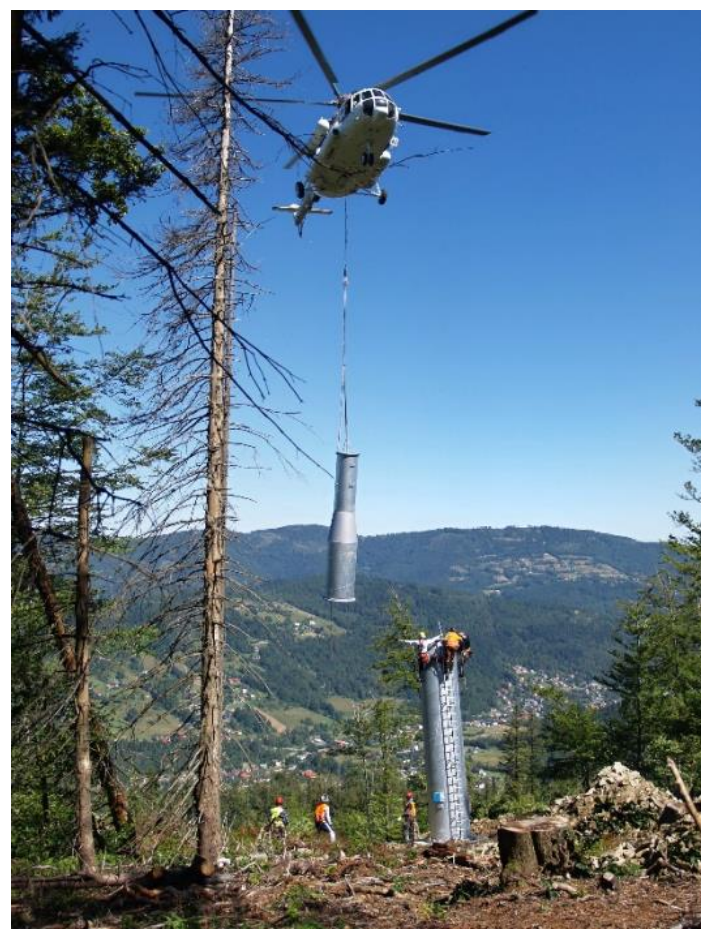

Obr. 5 Montáž podpier lanovej dráhy vrtul’níkom Mi-8 v súčasnosti (autori)

Letecké práce možno v Slovenskej republike vykonávat' len na základe povolenia vydaného Dopravným úradom (DÚ). DÚ v povolení určí rozsah a podmienky na vykonávanie leteckých prác. Na Slovensku v súčasnosti pôsobia, podla registra DÚ, Divízie civilného letectva, na trhu leteckých prác v oblasti stavebníctva dve spoločnosti: UTair Europe, s.r.o. (letisko Piešt’any) a TECH-MONT Helicopter company, s.r.o. (letisko Spišská Nová Ves) [6].

\section{LETECKÉ PRÁCE V STAVEBNOM PRIEMYSLE Z HL'ADISKA LOGISTIKY}

Praktické využitie vrtul'níkov v stavebníctve je ovplyvnené množstvom náhodne pôsobiacich faktorov, predovšetkým poveternostnými podmienkami. Klasické metódy časového a nákladového plánovania stavieb nedokážu tieto náhodné javy dostatočne zachytit', čo negatívne vplýva na celý proces realizácie výstavby. Autenticitu výstupov projektovej prípravy stavieb môžeme zvýšit' pomocou progresívnych nástrojov, medzi ktoré patrí aj simulačné modelovanie. Simulačné modelovanie, vychádzajúce z teórie pravdepodobnosti a matematickej štatistiky, sa dokáže lepšie priblížit' k premenlivej realite stavebnej výroby [7]. V oblasti prípravy stavieb sa na Slovensku využíva simulačný prístup zriedka, vo väčšej miere ho však už dnes použivajú iné výrobné odvetvia priemyslu, často napr. strojárstvo.

Overenie vhodnosti použitia simulačného modelovania $\mathrm{v}$ oblasti prípravy stavieb realizovaných vrtul'níkmi bolo hlavným ciel’om dizertačnej práce „Využitie simulačného modelovania pri príprave výstavbového procesu“ [8]. V dizertačnej práci sme sa zaoberali koncepciou, návrhom a implementáciou simulačného modelu leteckých prác, ktorý vnímame v širšom edukatívnom rámci so zameraním sa na možnosti využitia počítačovej simulácie pri príprave realizácie tohto typu stavieb [9, 10]. Podstatnou charakteristikou navrhnutého simulačného modelu je riešenie vplyvu poveternostných podmienok na realizáciu výstavby, ktorého algoritmus sme navrhli v spolupráci so Slovenským hydrometeorologickým ústavom (SHMÚ) na báze rôznych komerčne používaných numerických modelov predpovede počasia, ako sú modely IFS, ALADIN a A-LAEF [11, 12, 13]. Simulačný model sme zostavili v prostredí MATLAB (Obr. 6). 


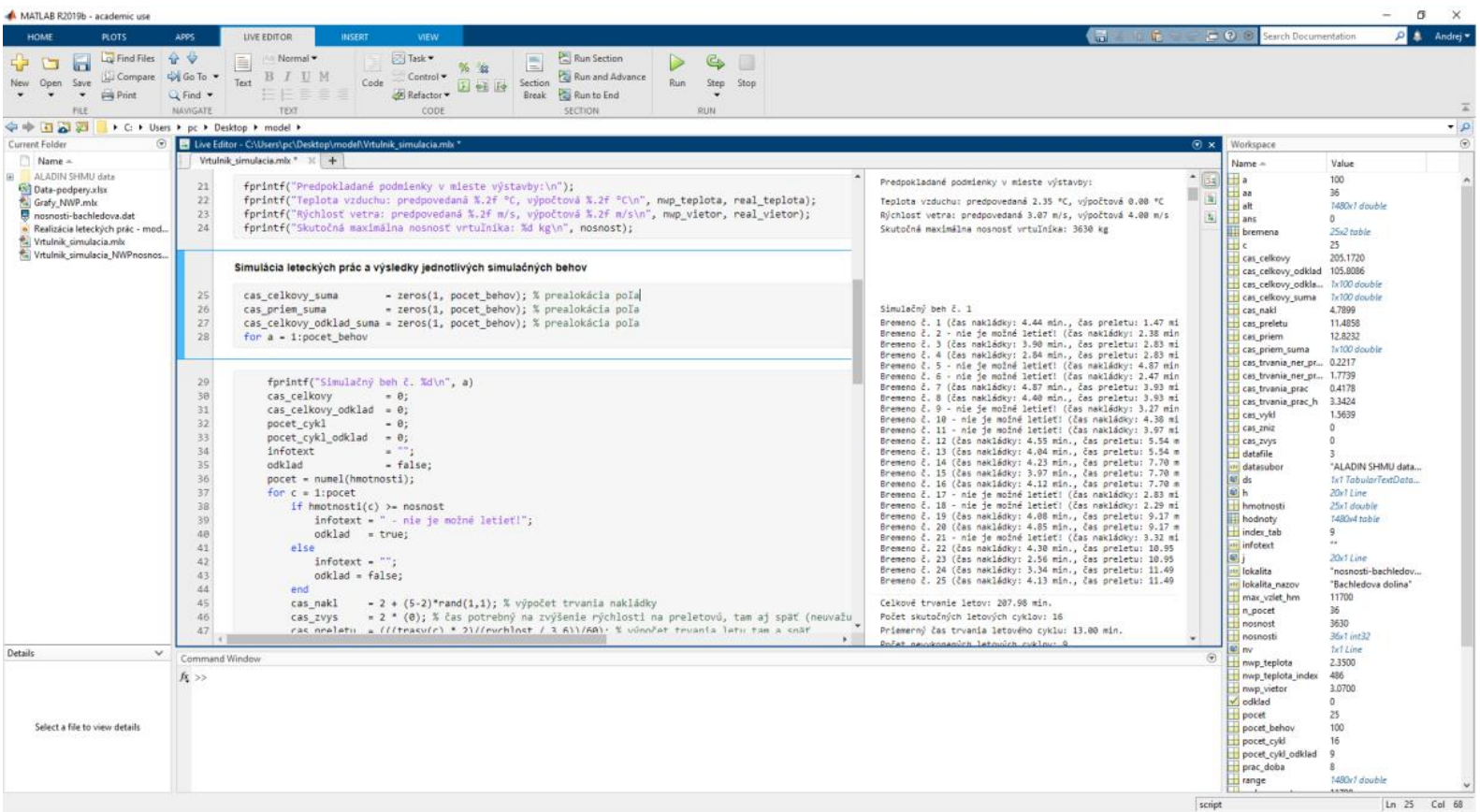

Obr. 6 Simulačný model leteckých prác v stavebníctve vytvorený ako tzv. live script v prostredí MATLAB

Na základe poznatkov získaných snímkovaním reálnych procesov, ako aj na základe relevantných informácií zo stavebnej praxe, sme navrhli a zostavili simulačný model leteckých prác a jeho možnosti preukázali na prípade výstavby kabínkovej lanovej dráhy v Bachledovej doline (Slovensko). Súčasne sme prezentovali široké možnosti uplatnenia numerických modelov predpovede počasia súčasnej úrovne, ktoré, ako také, predstavujú de facto „simulačný model v simulačnom modeli“ [14]. Výsledky získané simuláciou považujeme za vierohodné, pretože sa vel'mi približujú k tým, ktoré bývajú dosahované $\mathrm{v}$ praxi $\mathrm{v}$ prípade realizácií stavieb tohto typu a rovnako $\mathrm{v}$ plnom rozsahu odôvodňujú použitie simulácie pri príprave leteckých prác v stavebníctve. Koncepcia simulačného modelu leteckých prác je otvorená a umožňuje širšie využitie ako v celom segmente stavebnej výroby, tak v iných priemyselných odvetviach.

\section{ZÁVER}

Súdobý líder v riešenej problematike, niekdajší podnik Transporta Chrudim, akcentoval využitie vrtul'níkov pri montáži lanových dráh už od druhej polovice 60. rokov 20. storočia. Po dobrých skúsenostiach, nadobudnutých najmä v sektore lanovej dopravy, objavilo výhody využitia vrtul'níkov aj vtedajšie „konvenčné“ stavebníctvo. S vrtulníkom typu Mi-8 sa overili rôzne druhy stavebných prác a v nasledujúcich rokoch bolo použitie vrtul'níkov tohto typu zaradené do bežných technologických postupov.

Využitím vrtul'níkov získalo stavebníctvo prostriedok, ktorý umožňuje realizáciu výstavby aj v náročných prírodných podmienkach. Súčasne sa však zvýšili nároky na prípravu týchto stavebných prác. Ich plánovanie a organizácia si vyžaduje využitie modernejších prístupov, ako je napríklad simulačné modelovanie, pomocou ktorého sa vieme k realite priblížit' presnejšie, zachytit' všetky náhodné vplyvy a eliminovat' ich dôsledky. 21. storočie je dobou štvrtej priemyselnej revolúcie, ktorá má potenciál zmenit' od základov doterajšiu podobu mnohých l'udských činností. Nielen z tohto dôvodu sa s rôznymi dômyselnými aplikáciami informačných technológií budeme aj v oblasti stavebnej výroby stretávat' čoraz častejšie. 


\section{Poděkování}

Autori príspevku d’akujú pánovi Miroslavovi Holubovi, bývalému zamestnancovi Transporty Chrudim, za poskytnutie historických fotografií. Príspevok predstavuje čiastkový výstup riešenia projektu VEGA č. $1 / 0511 / 19$.

\section{Použitá literatura}

[1] MESSINGEROVÁ, V., 2005. Technológia vzdušnej dopravy dreva v lesníctve. Zvolen: Technická univerzita vo Zvolene. ISBN 80-228-1523-3.

[2] JINDRA, F., 1965. Stavebně montážní práce s využitím vrtulniků v ČSSR. Praha: NADAS.

[3] GREENWOOD, W., LYNCH, J., ZEKKOS, D., 2019. Applications of UAVs in Civil Infrastructure. Journal of Infrastructure Systems, 25(2). ISSN 1076-0342.: https://doi.org/10.1061/(ASCE)IS.1943-555X.0000464

[4] BOUDNÍK, J., DOSOUDIL, E., 1974. Využitie vrtulníkov v národnom hospodárstve. Bratislava: Dom techniky SVTS v Bratislave.

[5] HRUBEŠ, V., 1988. Využití vrtulníků v osmdesátých letech v ČSSR. In: Využitie vrtulníkov $v$ národnom hospodárstve - zborník prednášok, Tatranská Lomnica, 18. - 19.10.1988. Žilina: Dom techniky ČSVTS v Žiline, s. 16-19.

[6] DÚ (Dopravný úrad), 2021. Letecké práce [online]. Bratislava: Dopravný úrad [cit. 16. júla 2021]. Dostupné na: http://letectvo.nsat.sk/letova-prevadzka/osvedcenie-letovejsposobilosti/formulare/

[7] HULÍNOVÁ, Z., 2011. Analýza stavebných procesov z hladiska ich modelovania. Bratislava: Nakladatel'stvo STU. ISBN 978-80-227-3474-5.

[8] BISTÁK, A., HULÍNOVÁ, Z., 2020. Využitie simulačného modelovania pri príprave výstavbového procesu. Dizertačná práca.

[9] BISTÁK, A., 2017. Simulácia stavebných procesov realizovaných vrtul'níkmi: analýza a návrh koncepcie modelu. In: Advances in Architectural, Civil and Environmental Engineering: 27th Annual PhD Student Conference, 25. October 2017, Bratislava, Slovakia. Bratislava: Spektrum STU, s. 226-231. ISBN 978-80-227-4751-6.

[10] BISTÁK, A., 2018. Využitie simulačného modelovania pri príprave výstavbového procesu realizovaného technológiou leteckých prác. In: Advances in Architectural, Civil and Environmental Engineering: 28th Annual PhD Student Conference, October 24th 2018, Bratislava, Slovakia. Bratislava: Spektrum STU, s. 115-122. ISBN 978-80-227-4864-3.

[11] DERKOVÁ, M. et al., 2017. Recent improvements in the ALADIN/SHMU operational system. Meteorological Journal, 20(2), s. 45-52. ISSN 1335-339X.

[12] TERMONIA, P. et al., 2018. The ALADIN system and its canonical model configurations AROME CY41T1 and ALARO CY40T1. Geoscientific Model Development, 11(1), s. 257-281. ISSN 1991-9603. https://doi.org/10.5194/gmd-11-257-2018

[13] WANG, Y. et al., 2011. The Central European limited-area ensemble forecasting system: ALADIN-LAEF. Quarterly Journal of the Royal Meteorological Society, 137(655), s. 483-502. ISSN 1477-870X. Dostupné na internete: https://doi.org/10.1002/qj.751

[14] BISTÁK, A., HULÍNOVÁ, Z., NEŠTIAK, M., 2021. Simulation modelling of aerial works and its role in the preparation of construction. Slovak Journal of Civil Engineering, 29(1), s. 20-26. ISSN 1338-3973. https://doi.org/10.2478/sjce-2021-0004 